\title{
Effects of Guar (Cyamopsis tetragonoloba) Residues on the Performance and Nutrients Digestibility in Finishing Awassi Lambs
}

\author{
Jamal Abo Omar1", Ahmed Zaazaa1, Maen Sheqwarah², Bassam Abu Shanab1, \\ Wael Qaisi ${ }^{3}$, Jehad Abdallah ${ }^{1}$ \\ ${ }^{1}$ Department of Animal Production, Faculty of Agriculture, An Najah National University, Post Office 707, Nablus, Palestine \\ ${ }^{2}$ Faculty of Agriculture, Al Quds Open University, Ramallah, Palestine \\ ${ }^{3}$ National Agriculture Research Center (NARC), Ministry of Agriculture, Jenin City, Palestine \\ Email: *aboomar57@najah.edu
}

How to cite this paper: Abo Omar, J., Zaazaa, A., Sheqwarah, M., Shanab, B.A., Qaisi, W. and Abdallah, J. (2021) Effects of Guar (Cyamopsis tetragonoloba) Residues on the Performance and Nutrients Digestibility in Finishing Awassi Lambs. Open Journal of Animal Sciences, 11, 96-104. https://doi.org/10.4236/ojas.2021.111008

Received: October 28, 2020

Accepted: January 26, 2021

Published: January 29, 2021

Copyright $\odot 2021$ by author(s) and Scientific Research Publishing Inc. This work is licensed under the Creative Commons Attribution International License (CC BY 4.0).

http://creativecommons.org/licenses/by/4.0/

(c) (i) Open Access

\begin{abstract}
The nutritive quality of guar (Cyamopsis tetragonoloba) residues (GR) was investigated and the effects of partial replacement of wheat straw by GR on nutrients intake, digestibility, and growth performance. Twenty four male lambs, with average body weight $(\mathrm{BW})$ of $40.3 \pm 2.5 \mathrm{~kg}$ were divided into three groups. Lambs were fed individually for 104 days with concentrate mixture (18\% crude protein) and wheat straw as a total mixed ration. Wheat straw was replaced with 0,100 and $145 \mathrm{~g} / \mathrm{kg}$ dry matter guar residues. All rations were isonitrogenous and isocaloric. The fattening trial lasted 104 days. At the end of week 10 of the trail, a digestion trial was performed using six lambs from each group. The composition of nutrients in the GR was $87 \%$, 8.5\%, 56.4\% and $40.1 \%$ for DM, CP, NDF and ADF, respectively. DM and crude protein $(\mathrm{CP})$ intake were not affected by the inclusion of GR. However, neutral detergent fibre (NDF) and acid detergent fibre (ADF) intake were lower in lambs fed GR compared to control lambs. At the end of the experiment, lambs fed 100 and $145 \mathrm{~g} \mathrm{GR} / \mathrm{kg}$ DM diets gained more weight $(\mathrm{P}<$ $0.05)$ than those fed the control diet. The same trend was found for feed conversion (CR). Results from this work suggested that GR had advantages compared to regular roughage (wheat straw) in regard to parameters investigated as well as the significant reduction in fattening diets cost.
\end{abstract}

\section{Keywords}

Guar Residues, Awassi Lambs, Performance, Nutrients Digestibility 


\section{Introduction}

Agriculture in Palestine (Middle East) is dryland farming. Depending on the regional rainfall, the availability of forages and cereal crops is highly seasonal. In order to reduce feed cost, it is important to find more sources of cheap roughage as guar which is recently introduced to Palestine.

Guar (Cyamopsis tetragonoloba) is tolerant to drought [1], salinity [2] [3] and important to fix atmospheric nitrogen [4]. It is a multi-purpose annual herbaceous legume and fits well into most of the prevailing summer cropping systems [5] because it is a fast-growing crop and might be a solution to solve the problem of lack of roughage in summer season [6].

Guar originated in the hot and arid areas of Africa or the deserts of the Middle East [7]. It was estimated that guar seed productivity was about 1.6 tons/ha [8]. The majority of guar seeds are utilized in the production of guar gum from the endosperm. The resulting by-products (i.e. germ and husks) are rich in protein and carbohydrates [9]. Feeding guar residues at 2.44 percent of body weight maintained rams body weight [10]. Similarly, guar hay when fed to goats it caused no adverse effects on dry matter intake and nutrient digestibility [11]. Improvement of body weight and milk production was observed when feeding guar hay to goats, with recommendations of the positive effects on the general performance of goats [12].

There is a lack of information about the nutritive profile of (GR) in Palestine as a summer legume roughage and its effect on livestock performance.

The objectives of this study were to investigate the nutritive value of GR and the effects of partial replacement of wheat straw by GR on the nutrient intake, growth performance, and digestibility in finishing Awassi fattening lambs.

\section{Materials and Methods}

The study site is considered as a semiarid area at an altitude of $150 \mathrm{~m}$. The soil within the area is sandy loam. The annual rainfall is $500 \mathrm{~mm}$ in a season beginning from September until April.

Guar crop was harvested 90 days after sowing where it was fully mature. The crop was threshed and cut into pieces of $1 \mathrm{~cm}$ length and seeds were removed. The remains, mainly stem, the portion of leaves, and little seeds, were collected as the GR that was incorporated in the fattening lambs' rations.

\subsection{Animals and Diets}

Care, handling, and sampling procedures were approved by the An Najah National University (Nablus, Palestine), Animal Care and Use Committee before initiation of the trial.

This experiment was conducted at a private farm near Jenin city/Palestinian territories. A total of 24 weaned male finishing Awassi lambs, with a mean weight of $40.3 \pm 2.5 \mathrm{~kg}$ ) and four months of age were used.

Experimental treatments were given to animals by stratified randomization on 
the basis of live body weight (BW), resulting in three groups of lambs with a similar distribution of initial BW. Lambs were fed individually and each lamb was considered as a replicate.

Lambs were fed a fattening concentrate and wheat straw -based total mixed rations (Table 1), where wheat straw was partially substituted by GR at the following levels:

1) A control group without GR (CON; $n=8)$.

2) A $100 \mathrm{~g} \mathrm{GR} / \mathrm{kg}$ DM diet group (GR100; $n=8$ ).

3) A 145 g GR/kg DM diet group (GR145; $n=8$ ).

All diets were isonitrogenous/isocaloric, formulated to have 14\% CP (DM basis) according to the National Research Council (NRC) [13].

Lambs were housed individually in $1 \mathrm{~m} \times 1 \mathrm{~m}$ pens. Fresh drinking water was always made available.

\subsection{Experimental Procedure}

The amounts of feed offered and refused were weighed daily and samples were collected for subsequent analyses. The amount of feed offered was adjusted daily on the basis of the previous day's intake, allowing refusals of $15 \%$ to $20 \%$. Animals were weighed before morning feeding at a weekly basis.

\subsection{Laboratory Analyses}

Samples of diets and GR were sun dried, ground (1-mm screen) and stored for

Table 1. The ingredients and chemical composition of experimental feeds given to Awassi lambs (\%).

\begin{tabular}{cccc}
\hline & \multicolumn{3}{c}{ Treatment } \\
\cline { 2 - 4 } & C & GR1 & GR2 \\
\hline Concentrated feed & 71.0 & 71.0 & 71.0 \\
Wheat straw & 29.0 & 19.0 & 14.5 \\
GR & 0 & 10.0 & 14.5 \\
Chemical analysis (DM basis) & & & \\
DM & 90.0 & 89.6 & 90.5 \\
CP & 14.0 & 13.9 & 14.3 \\
ADF & 18.5 & 17.8 & 16.6 \\
aNDF & 55.0 & 46.9 & 45.3 \\
Ash & 7.0 & 6.8 & 6.6 \\
Ca & 1.01 & 1.15 & 1.11 \\
P & 0.43 & 0.53 & 0.58 \\
ME & 1540 & 1530 & 1530 \\
\hline
\end{tabular}

*Composition per $1 \mathrm{~kg}$ contained, yellow corn, $600 \mathrm{~g} / \mathrm{kg}$; soybean meal, $269 \mathrm{~g} / \mathrm{kg}$; wheat bran, $100 \mathrm{~g} / \mathrm{kg}$; ammonium chloride, $3 \mathrm{~g} / \mathrm{kg}$; dicalcium phosphate, $6 \mathrm{~g} / \mathrm{kg}$; limestone, $17 \mathrm{~g} / \mathrm{kg} ; \mathrm{NaCl}, 3 \mathrm{~g} / \mathrm{kg} ; \mathrm{premix}, 1 \mathrm{~g} / \mathrm{kg}$ (Composition per $1 \mathrm{~kg}$ contained, vitamin A, 2,000,000 IU; vitamin D3, 40,000 IU; vitamin E, $400 \mathrm{IU}$; Mn, $12.8 \mathrm{mg}$; Zn, $9.0 \mathrm{mg}$; I, $1.56 \mathrm{mg}$; Fe, $6.42 \mathrm{mg}$; Co, $50 \mathrm{mg}$; Se, $32 \mathrm{mg}$ plus an antioxidant); soap stock, $1 \mathrm{~g} / \mathrm{kg}$. ${ }^{* *}$ Metabolizable energy; based on tabular values (NRC, 1985). 
subsequent analysis.

Dry matter (DM) was determined by drying at $105^{\circ} \mathrm{C}$ until constant weight. The mineral content was then determined by ashing at $600^{\circ} \mathrm{C}$ for $8 \mathrm{~h}$. Nitrogen was determined by the Kjeldahl method ( $\mathrm{CP}=\times 6.25)$; Association of Analytical Communities [14]. NDF and ADF were determined according to Van Soest et al. [15].

The samples were analyzed for the mineral elements using atomic absorption spectrophotometer (Shimadzu 650 model), whereas $\mathrm{K}$ and $\mathrm{Na}$ were determined using flame photometry.

\subsection{Digestibility Study}

Apparent digestion coefficients of the three diets fed to lambs were determined using six lambs per group. Animals were fed at $1.1 \times$ maintenance energy requirements. Lambs were put on the experimental diets for two weeks before being placed in metabolic crates for 14 days. The first 7 days served as an adaptation period and the other as the total collection period.

At the end of the collection period, a composite sample was prepared for each lamb. The dried sample was ground in a Wiley mill with a $2-\mathrm{mm}$ screen. Samples of feed, orts, and urine also were taken daily for each lamb. Wet feces were analyzed for nitrogen by the Kjeldahl method. Gross energy of feed, orts, and wet feces was measured by Parr oxygen bomb calorimeter.

\subsection{Statistical Methods}

Data were subjected to ANOVA for a completely randomized design using the general linear procedure of SAS [16]. Differences among treatment mean for significant dietary effects were detected using the LSD procedure of SAS. Unless otherwise stated, significance was declared at $\mathrm{P}<0.05$.

\section{Results}

\subsection{Chemical Composition of Guar Residues}

The chemical analysis of the GR is presented in Table 2. Crude protein content was $850 \mathrm{~g} / \mathrm{kg}$ DM. The NDF, ADF and lignin values were 564, 401, and $40 \mathrm{~g} / \mathrm{kg}$, respectively. Mineral contents were $8.6,1.9 \mathrm{~g} / \mathrm{kg} \mathrm{DM}$ for calcium and phosphorus, respectively and $29 \mathrm{ppm}$ for manganese.

\subsection{Nutrients Intake and Lambs Growth}

The DM and CP intake was not affected $(P>0.05)$ by feeding GR as part of diets (Table 3). However, GR decreased $(P<0.05)$ the NDF and ADF intakes at both levels.

Lambs' total gain, ADG and feed CR were significantly higher $(P<0.05)$ in lambs fed the GR at 100 and $145 \mathrm{~g} / \mathrm{kg}$ of the fattening diets compared to that of finishing lambs fed a regular fattening diet (CON) (Table 3).

\subsection{Digestibility}

The inclusion of GR as part of the fattening diets significantly improved $(\mathrm{P}<$ 
Table 2. Chemical composition of guar residues (GR) used in the experiment ${ }^{1}$.

\begin{tabular}{cc}
\hline Parameter & $\%$ \\
\hline Dry matter & 87.0 \\
Crude protein & 8.5 \\
Crude fat & 1.12 \\
Crude fiber & 37.0 \\
NDF & 56.4 \\
ADF & 401.0 \\
Lignin & 40.0 \\
Calcium & 0.86 \\
Phosphorus & 0.19 \\
Manganese & $29 \mathrm{ppm}$ \\
\hline
\end{tabular}

${ }^{1}$ Analysis at An Najah National University labs.

Table 3. DM, CP, NDF, ADF intake, digestibility of nutrients and performance ADG and CR of Awassi lambs fed different levels of guar residues (GR).

\begin{tabular}{ccccc}
\hline & \multicolumn{4}{c}{ Treatment } \\
\cline { 2 - 5 } & CON & GR1 & GR2 & GR effect \\
\hline Dry matter & & & \\
Intake, g/d & 1914.0 & 1872.6 & 1868.2 & 0.67 \\
Digestibility, \% & $71.0^{\mathrm{b}}$ & $75.0^{\mathrm{a}}$ & $78.8^{\mathrm{a}}$ & 0.05 \\
Crude protein & & & & \\
Intake, g/d & 267.0 & 262.1 & 267.2 & 0.58 \\
Digestibility, \% & 71.0 & 74.0 & 75.0 & 0.21 \\
Neutral detergent fiber & & & & \\
Intake, g/d & $1052.7^{\mathrm{a}}$ & $880.1^{\mathrm{b}}$ & $846.3^{\mathrm{b}}$ & 0.05 \\
Digestibility, \% & $50.0^{\mathrm{b}}$ & $56.0^{\mathrm{a}}$ & $58.0^{\mathrm{a}}$ & 0.05 \\
Acid detergent fiber & & & & \\
Intake, g/d & $354.1^{\mathrm{a}}$ & $330.3^{\mathrm{b}}$ & $310.0^{\mathrm{b}}$ & 0.05 \\
Digestibility, \% & $44.0^{\mathrm{b}}$ & $50.0^{\mathrm{a}}$ & $54.0^{\mathrm{a}}$ & 0.05 \\
Average daily gain, g/d & $220^{\mathrm{b}}$ & $280^{\mathrm{a}}$ & $310^{\mathrm{a}}$ & 0.05 \\
Feed conversion & $8.9^{\mathrm{b}}$ & $7.0^{\mathrm{a}}$ & $7.3^{\mathrm{a}}$ & 0.05 \\
Cost of gain, \$ & $30^{\mathrm{b}}$ & $26.2^{\mathrm{a}}$ & $25.1^{\mathrm{a}}$ & 0.05 \\
\hline
\end{tabular}

$\mathrm{DMI}=$ dry matter intake; $\mathrm{ADG}=$ average daily gain; $\mathrm{FCR}=$ feed conversion ratio; $\mathrm{GR}=$ guar residues. ${ }^{\mathrm{a}, \mathrm{b}}$ Values within a row with different superscripts differ significantly at $P<0.05$.

0.05) the DM, NDF, and ADF digestibility (Table 3). The DM. NDF and ADF digestibility was improved by $8 \%, 14 \%$, and $18 \%$ when incorporated at 100 and $145 \mathrm{~g} / \mathrm{kg}$ of the fattening diets, respectively compared to control. However, GR had no effect on CP digestibility. 


\subsection{Cost of Gain}

Incorporation of GR in diets reduced $(P<0.05)$ the cost of 1 ton of diet by 17 and 25 , and cost of total gain by 5.5 and 9.9 by feeding GR at levels of 100 and $145 \mathrm{~g} / \mathrm{kg} \mathrm{DM}$, respectively.

\section{Discussion}

The results of this detailed investigation are the first to be reported regarding GR at Palestinian conditions. The nutritive profile of GR shows similar forage and hay quality compared to summer crops especially some legumes [17], it is of higher nitrogen concentration and lower cell wall components than the common forage grasses like Sudan grass and pearl millet [17] and fodder maize [18].

Crude protein content as indicated in this research was $85 \mathrm{~g} / \mathrm{kg}$ DM which is of higher value compared to most of the traditionally used roughages (wheat and barley straw, olive cake) for different classes of livestock under local conditions. Fibrous components of GR are high due to the maturity of the GR depending largely on the proportion of stems in GR. Late harvesting was reported for fodder sorghum [19] and [20], fodder maize [21], millet [22], and forage turnip [23] to increase cell wall contents significantly.

This study showed that the NDF, ADF and lignin levels in GR were 564, 401 and $45 \mathrm{~g} / \mathrm{kg} \mathrm{DM}$, respectively. The value of these parameters wheat straw was 780, 500 and $15 \mathrm{~g} / \mathrm{kg}$ DM for NDF, ADF and lignin, respectively.

Results of this research showed that Ca, P, manganese values $(8.6,19 \mathrm{~g} / \mathrm{kg} \mathrm{DM}$ and $29 \mathrm{ppm})$ were lower than that in wheat straw $(45,7 \mathrm{~g} / \mathrm{kg}$ and $46 \mathrm{ppm})$.

Feed DM and CP intake were not affected by feeding GR, this result is in agreement with previous research [24] [25] [26].

The ADG and FCR were improved by the incorporation of GR in the finishing fattening diets. The FCR was improved by $20 \%$. Similar results were reported by Makki [27]. Guar bean crop residues (straw) can be incorporated up to $700 \mathrm{~g} / \mathrm{kg}$ in the maintenance ration without any adverse effects [28] [29] reported that guar bean straw can also be used for feeding camels.

The digestibility coefficients of DM, NDF and ADF were improved by GR feeding. On average the GR at both levels in rations improved the DM. NDF and ADF digestibility by $8 \%, 14 \%$ and $18 \%$, respectively compared to the control, the low inclusion levels in fattening rations of GR in lambs' could explain the lack of negative effects of some antinutritional factors in guar residues that were proposed by previous research [30].

The cost of rations and cost of gain was significantly reduced by incorporation of GR. A ton of ration cost reduced by 17 and $25 \$$, while cost of total gain was reduced by 5.5 and 9.9 by feeding GR at levels of 100 and $145 \mathrm{~g} / \mathrm{kg} \mathrm{DM}$, respectively. On average the reduction of gain costs was decreased by $14.5 \%$ compared to the cost of gain in control lambs, therefore, significant savings could be achieved through utilizing GR in fattening rations under local condition, where roughage cost is increasing. 


\section{Conclusion}

The current results showed that growing guar under Palestinian conditions was characterized by fodder and hay quality comparable to other summer forage legumes, and higher than summer forage grasses. The problem of feed shortage during the summer season would be solved through utilizing GR which has a good acceptable feeding value.

\section{Acknowledgements}

The authors wish to thank An Najah National University and the staff of the National Agriculture Research Center, NARC, (Palestinian ministry of Agriculture), especially, Eng. Medhat Weld Ali, Eng. Fathi Neirat, Maisan Al Jammal and Oday Zaid. The study was developed under the framework of the FAO project "Supporting economic growth through optimized value chains in the West Bank" Funded by the Government of Canada.

\section{Conflicts of Interest}

The authors declare no conflicts of interest regarding the publication of this paper.

\section{References}

[1] Garg, B.K. and Burman, U. (2002) Physiology. Scientific Publishers, Judhpur, 63-84.

[2] Francois, L.E., Donovan, T.J. and Maas, E.V. (1990) Salinity Effects on Emergence, Vegetative Growth and Seed Yield of Guar. Agronomy Journal, 82, 587-592. https://doi.org/10.2134/agronj1990.00021962008200030030x

[3] Ashraf, M.Y., Akhtar, K., Sarwar, G. and Ashraf, M. (2005) Role of Rooting System in Salt Tolerance Potential of Different Guar Accessions. Agronomy for Sustainable Development, 25, 243-249. https://doi.org/10.1051/agro:2005019

[4] Ahmad, J. (2008) Effect of Different Levels of Phosphorous and Potassium on Growth, Forage Yield and Quality of Cluster Bean. M.Sc. Thesis, University of Agriculture Faisalabad, Pakistan.

[5] Ashraf, M.Y., Akhtar, K., Sarwar, G. and Ashraf, M. (2002) Evaluation of Arid and Semi-Arid Ecotypes of Guar (Cyamopsis tetragonoloba L.) for Salinity $(\mathrm{NaCl})$ Tolerance. Journal of Arid Environments, 52, 473-482. https://doi.org/10.1006/jare.2002.1017

[6] Farrag, A.A. and Abd El-Latif, E.M. (1997) Effect of NPK Combination on Growth and Yield of Guar (Cyamopsis tetragonoloba (L.) Taub.). Al-Azhar Journal of Agricultural Research, 23, 15-25.

[7] FAO (2010) Ecoport. Ecoport Database. http://www.eecoport.org

[8] Lee, J.T., Connor-Appleton, S., Haq, A.U., Bailey, C.A. and Cartwright, A.L. (2004) Quantitative Measurement of Negligible Trypsin Inhibitor Activity and Nutrient Analysis of Guar Meal Fractions. Journal of Agricultural and Food Chemistry, 52 6492-6495. https://doi.org/10.1021/jf049674+

[9] Lee, J.T., Bailey, C.A. and Cartwright, A.L. (2009) In Vitro Viscosity as a Function of Guar Meal and Beta-Mannanase Content of Feeds. International Journal of Poul try Science, 8, 715-719. https://doi.org/10.3923/ijps.2009.715.719 
[10] Patnayak, B.C., Mohan, M., Bhatia, D.R. and Hajra, A. (1979) A Note on the Nutritional Value of Cowpea, Moth (Dewgram) and Clusterbean Fodders Fed as Hay to Sheep. Indian Journal of Animal Sciences, 49, 746-748.

[11] Pachauri, V.C. and Upadhyaya, R.S. (1986) Nutritive Value of Cluster Bean (Cyamopsis tetragonoloba) Hay as Affected by Supplementation of Oat Grain in Goats. Indian Journal of Animal Sciences, 56, 154-155.

[12] Zahid, M.S, Majid, A., Rischkowsky, B., Khan, S., Hussain, A., Shafeeq, S., Gurmani, Z.A., Munir, M., Rahman, S. and Iimran, M. (2012) Improved Goats Milk and Meat Production. Sarhad Journal of Agriculture, 28, 477-483.

[13] National Research Council (1985) Nutrient Requirements of Sheep. 6th Edition, National Academy Press, Washington DC.

[14] Association of Official Analytical Chemists (1990) Official Methods of Analysis of the AOAC. AOAC, Arlington.

[15] Van Soest, P.J., Robertson, J.B. and Lewis, B.A. (1991) Methods for Dietary Fiber, Neutral Detergent Fiber, and Nonstarch Polysaccharides in Relation to Animal Nutrition. Journal of Dairy Science, 74, 3583-3597. https://doi.org/10.3168/jds.S0022-0302(91)78551-2

[16] SAS, Statistical Analysis System Institute (1989) SAS/STATTM User's Guide: Statistics, Cary, USA.

[17] Salama, H.A.S. and Zeid, M.K. (2016) Hay Quality Evaluation of Summer Grass and legume Forage Monocultures and Mixtures Grown under Irrigated Conditions. Australian Journal of Crop Science, 10, 1543-1550. https://doi.org/10.21475/ajcs.2016.10.11.PNE113

[18] Dahmardeh, M., Ghanbari, A., Syasar, B. and Ramrodi, M. (2009) Intercropping Maize (Zea mays L.) and Cow Pea (Vigna unguiculata L.) as a Whole-Crop Forage: Effects of Planting Ratio and Harvest Time on Forage Yield and Quality. Journal of Food, Agriculture and Environment, 7, 505-509.

[19] Ayub, M., Nadeem, M.A., Tanveer, A. and Husnain, A. (2002) Effect of Different Levels of Nitrogen and Harvesting Times on the Growth, Yield and Quality of Sorghum Fodder. Asian Journal of Plant Sciences, 1, 304-307. https://doi.org/10.3923/ajps.2002.304.307

[20] Atis, I., Konuskan, O., Duru, M. and Yilmaz, S. (2012) Effect of Harvesting Time on Yield, Composition and Forage Quality of Some Forage Sorghum Cultivars. International Journal of Agriculture and Biology, 14, 874-886.

[21] Shehzad, M.A., Maqsood, M., Bhatti, M.A., Ahmad, W. and Shahid, M.R. (2012) Effects of Nitrogen Fertilization Rate and Harvest Time on Maize (Zea mays L.) Fodder Yield and Its Quality Attributes. Asian Journal of Pharmaceutical and Biological Research, 10, 2-19.

[22] Tariq, M., Ayub, M., Elahi, M., Ahmad, A.H., Chaudhary, M.N. and Nadeem, M.A. (2011) Forage Yield and Some Quality Attributes of Millet (Pennisetum americannum L.) Hybrid under Various Regimes of Nitrogen Fertilization and Harvesting Dates. African Journal of Agricultural Research, 6, 3883-3890.

[23] Tiryakioglu, H. and Turk, M. (2012) Effects of Different Sowing and Harvesting Times on Yield and Quality of Forage Turnip (Brassica rapa L.) Grown as a Second Crop. Turkish Journal of Field Crop, 17, 166-170.

[24] Chanil, L.M. and Rathee, A. (1983) Urea Acid Feed Supplements to Improve Poor Quality Roughage. Journal of Dairy Science, 39, 162-165.

[25] Soliman, M.S., El-Okazy, A.M. and Abu Hafsa, S.H. (2014) Effect of Partially or To- 
tally Replacing Soybean Meal by Guar Korma Meal on Sheep and Cow's Performance Milk Production. Journal of Animal and Poultry Production, 5, 43-55. https://doi.org/10.21608/jappmu.2014.68607

[26] Vatandoust, A.A., Naserian, F., Boldaje, S. and Zerhdaran, A. (2011) Effect of Feeding Different Levels of Guar Meal on Performance of Holstein Dairy Cows. Journal of Dairy Science, 93, E-Suppl. 1.

[27] Makki, M. (1998). Use of Guar (Cyamopsis tetragonolobba) Germ in the Diet of Sheep. M.Sc. Thesis, University of Khartoum, Khartoum.

[28] Singh, N., Arya, R.S., Sharma, T., Dhuria, R.K. and Garg, D.D. (2008) Effect of Feeding of Cluster Bean (Cyamopsis tetragonoloba) Straw Based Complete Feed in Loose and Compressed form on Rumen and Haemato-Biochemical Parameters in Marwari Sheep. Veterinary Practitioner, 9, 110-115.

[29] Bhakat, C., Saini, N. and Pathak, K.M.L. (2009) Comparative Study on Camel Management Systems for Economic Sustainability. Journal of Camel Practice and Research, 16, 77-81.

[30] Ahmed, M.B., Hamed, R.A., Ali, M.E., Hasssan, A.B. and Babiker, E.E. (2006) Proximate Composition, Antinutritional Factors and Protein Fractions of Guar Gum Seeds as Influenced by Processing. Pakistan Journal of Nutrition, 5, 481-484.

https://doi.org/10.3923/pjn.2006.481.484 